\title{
Biomphalaria tenagophila: dynamics of populations of resistant and susceptible strains to Schistosoma mansoni, with or without pressure of the parasite
}

\author{
Florence Mara Rosa, Ana Lúcia Brunialti Godard*, Deborah Negrão-Correa, \\ Horácio Antonio Rodrigues*, Omar dos Santos Carvalho**, Roberta Lima Caldeira**, \\ Horácio Manoel Santana Teles*** Engels Maciel****, Liana Konovaloff Jannotti-Passos**, \\ Paulo Marcos Zech Coelho $* * / * * * * * /+$
}

\begin{abstract}
Departamento de Parasitologia *Departamento de Biologia Geral, Instituto de Ciências Biológicas, UFMG, Belo Horizonte, MG, Brasil **Centro de Pesquisas René-Rachou-Fiocruz, Av. Augusto de Lima 1715, 30190-002 Belo Horizonte, MG, Brasil ***Superintendência de Controle de Endemias do Estado de São Paulo, São Paulo, SP, Brasil ****Chácara Santa Inês, Bananal, SP, Brasil *****Santa Casa de Misericórdia de Belo Horizonte, Belo Horizonte, MG, Brasil
\end{abstract}

Resistant (Taim, RS) and susceptible albino (Joinville, SC) Biomphalaria tenagophila populations were kept together, at different proportions, throughout a 18-month-period. Some of the snail groups were submitted to Schistosoma mansoni infection. The targets of this study were (a) to analyze the populational dynamics among resistant and susceptible individuals to S. mansoni; (b) to study the resistance phenotype in descendants of crossbreeding; (c) to observe whether the parasite could exert any kind of selection in those snail populations. Throughout the experiment it could be observed that the susceptible B. tenagophila strain (Joinville) underwent a selective pressure of the parasite that was negative, since the individuals showed a high mortality rate. Although B. tenagophila (Taim) population presented a higher mortality rate without pressure of the parasite, this event was compensated by a reproductive capacity. B. tenagophila Taim was more fecund than B. tenagophila Joinville and was able to transmit the resistance character to their descendants. $F_{1}$ generation obtained by cross-breeding between resistant and susceptible lineages was completely resistant to $\mathrm{S}$. mansoni infection, irrespective of the Taim proportion. Moreover, less than $5 \%$ of $F_{2}$ progeny were susceptible to S. mansoni infection.

Key words: Biomphalaria tenagophila - dynamics of populations - Schistosoma mansoni - resistant and susceptible strains

Distribution of Biomphalaria tenagophila snails has considerably been spread through the Brazilian territory, and its importance in the transmission of schistosomiasis has been increased as well, mainly in the Southern and Southeastern regions of Brazil (Paraense \& Corrêa 1987). This is the only transmitter species in extensive areas of the state of São Paulo, and it is responsible for isolated focuses in the states of Minas Gerais, Santa Catarina, and Rio de Janeiro.

Paraense and Corrêa (1978) demonstrated that $B$. tenagophila from different localities presented diversified susceptibility levels, when submitted to the SJ strain (São José dos Campos, SP) of Schistosoma mansoni. Santos et al. (1979) carried out a study with B. tenagophila dealing with two interesting susceptibility profiles: a $100 \%$ susceptible strain (Cabo Frio, RJ) and another one highly resistant (Taim, RS). This resistant strain proceeds from the Ecological Station at Taim, state of Rio Grande do Sul, and has been the target of several studies. These snails, at different ages, have continuously been resistant to various strains of $S$. mansoni, as well as to different bur-

Financial support: CNPq-Fapemig-Pronex

${ }^{+}$Corresponding author: coelhopm@cpqrr.fiocruz.br

Received 25 May 2006

Accepted 26 June 2006 dens of miracidia. The detected resistance was not due to the result of a physiological incompatibility between hostparasite, rather than to the innate defense system of the mollusc itself (Coelho et al. 2004).

Resistance in B. tenagophila, as well as in B. glabrata, is also associated with genetic factors. Previous studies dealing with cross breedings between $B$. tenagophila from Taim/RS and susceptible specimens of $B$. tenagophila from $\mathrm{BH} / \mathrm{MG}$ and Joinville/SC showed that $\mathrm{F}_{1}$ descendants, as a result of such cross-breedings, presented low suscetibility levels to S. mansoni (Santos et al. 1979, Freitas et al. 1985). Recently, several cross-breedings were carried out using a resistant strain (B. tenagophila Taim) and a susceptible albino one (B. tenagophila Joinville). Studying the phenotype of $\mathrm{F}_{1}$ and $\mathrm{F}_{2}$ descendants of those cross-breedings, it was observed that the resistance character could be determined by two dominant genes, and probably some genetic and environmental factors could modulate this response (Rosa et al. 2005).

Since the resistance in $B$. tenagophila has a dominant character, and also thinking in obtaining a possible model for transmission control, we initiated another kind of study. Populations of resistant (Taim, RS) and susceptible albino (Joinville, SC) B. tenagophila were maintained together, at different proportions, with and without $S$. mansoni pressure.

The idea is to analyze the genic flux of the alleles involved in the resistance character, and to evaluate the hypothesis related to the selective advantage for the re- 
sistant lineage when compared with the susceptible one, when both are under $S$. mansoni pressure.

\section{MATERIALS AND METHODS}

Snails - The pigmented B. tenagophila Taim strain, that was originally collected at the Ecological Station at Taim, state of Rio Grande do Sul, Brazil, has been completly resistant to experimental infection with S. mansoni (Santos et al. 1979). This strain has been maintained at the Laboratory of Schistosomiasis, Department of Parasitology, UFMG, Brazil, for more than 27 years, without any kind of selecting favoring the resistance character, since these snails are naturally resistant to $S$. mansoni. The albino $B$. tenagophila strain was originally collected at Joinville area, state of Santa Catarina, Brazil, by Dr Lobato Paraense that kindly provided the Joinville snail strain to be used in our experiments. In previous experiments, we observed that $B$. tenagophila Joinville was highly susceptible to different $S$. mansoni strains, such as $S$. mansoni $\mathrm{SJ}$ - isolated from infected snails from São José dos Campos/SP and $S$. mansoni LE - isolated from an infected pacient from Belo Horizonte/MG.

Parasite - The LE strain of S. mansoni, isolated from a patient in Belo Horizonte, Minas Gerais, Brazil, was used in all the experiments described bellow. This parasite strain has been maintained by successive passages through $B$. glabrata and hamsters (Mesocricetus auratus).

Cross-breeding -Ten parental groups were assembled with 50 young snails, measuring 3-4 $\mathrm{mm}$ of shell-diameter, placed into plastic vessels with approximately 301 dechlorinated water and fed with lettuce. Each group consisted of B. tenagophila Taim and/or B. tenagophila Joinville in the following proportions: Group 1: 50 pigmented $B$. tenagophila Taim (only parasite resistant snails); Group 2: 50 albino $B$. tenagophila Joinville (only parasite susceptible snails); Group 3: 25 resistant snails and 25 susceptible snails; Group 4: 40 susceptible snails and 10 resistant snails; Group 5: 40 resistant snails and 10 susceptible snails. The groups $1-5$ were not infected. The groups 6-10 were assembled with the same snail proportion than groups $1-5$, however the groups $6,7,8,9$, and 10 were submitted to the parasite pressure, as detailed bellow. The cross-breedings are summarized in Table I.

Each group was kept for 60 days, so the snails could reach sexual maturity. After this period, the snails of groups

\section{TABLE I}

Schedule of the parental groups submitted or not to Schistosoma mansoni pressure

\begin{tabular}{ll}
\hline Uninfected group & Infected group \\
\hline $1-50 \mathrm{R}$ & $650 \mathrm{R}$ \\
$2-50 \mathrm{~S}$ & $7-50 \mathrm{~S}$ \\
$3-25 \mathrm{~S}+25 \mathrm{R}$ & $8-25 \mathrm{~S}+25 \mathrm{R}$ \\
$4-40 \mathrm{~S}+10 \mathrm{R}$ & $9-40 \mathrm{~S}+10 \mathrm{R}$ \\
$5-40 \mathrm{R}+10 \mathrm{~S}$ & $10-40 \mathrm{R}+10 \mathrm{~S}$ \\
\hline
\end{tabular}

R: resistant pigmented (B. tenagophila Taim); S: susceptible albino (B. tenagophila Joinville).
6 to 10 were infected with $S$. mansoni miracidia every week, for 8 weeks, and the fecundity parameters and survival rates of each group were analyzed for 10 consecutive weeks. Fifty pigmented $F_{1}$ snails, randomly obtained from each parental group, were assembled in 10 new groups to obtain the $\mathrm{F}_{2}$ generation. This $\mathrm{F}_{2}$ progeny was kept and analyzed as described for the parental group.

Fecundity parameters - After the snails had reach sexual maturity, styrofoam strips were placed on the water surface of each plastic vessel, to be used as support for snails egg-masses deposition. The styrofoam strips were recovered weekly, and replaced by new ones to evaluate the group fecundity. The strips were analyzed under stereomicroscope and the number of egg-masses, the number of eggs/egg masses and number of eggs/snail were estimated for each group during 10 consecutives weeks of examination. In case of need, the results were statistically compared, the Wilcoxon test being used for the non-parametric data, and the paired Student's " $t$ " test for the parametric ones. The total number of the surviving snails in each experimental group and the phenotypic parameter (pigmentation) were analized 30 days after eclosion.

Snail infection - The snails were infected with miracidia of $S$. mansoni isolated from livers of hamster infected for 45-50 days, according to Pellegrino and Katz (1968). For the infection of breeding groups 6 to 10, the miracidia were counted and added directly to the vessels where the snails were kept. Each group received 200 miracida/week and the infection was accumulative, since this procedure was performed for 8 consecutive weeks.

To test susceptibility level of $F_{1}$ and $F_{2}$ progenies, 50 young individuals (3-4 $\mathrm{mm}$ ) of each cross-breeding were exposed to $S$. mansoni infection. For this purpose, each snail was individually exposed to 30 miracidia.

Methods for analysis of snail infection - Aiming at verifying the emergence of $S$. mansoni cercariae, the $\mathrm{F}_{1}$ and $F_{2}$ infected snails were individually observed under a stereomicroscope, every week between 40 and 90 days after exposure to miracidia. For examination of cercarial shedding, each snail was kept in small Snap-cap glass recipients, with dechlorinated water, and exposed to artificial light for $2 \mathrm{~h}$ (Pellegrino \& Katz 1968). After this period, the negative snails were squeezed between slide and coverslip in search for sporocysts.

\section{RESULTS}

In this study, it was verified that S. mansoni is a negative factor of selective pressure for the susceptible population. As can be observed in Fig. 1A, the individuals pertaining to B. tenagophila Taim (Group 1) or Joinville (Group 2) populations had a high survival rate, 90 and $97 \%$ respectively, when the populations were kept isolated and not exposed to parasite infection. In contrast, the survival rate of $B$. tenagophila Joinville dropped to $60 \%$ when the snail population was exposed to the parasite (Group 7), whereas no difference in the survival rate of B. tenagophila Taim was detected after parasite infection (Group 6). 

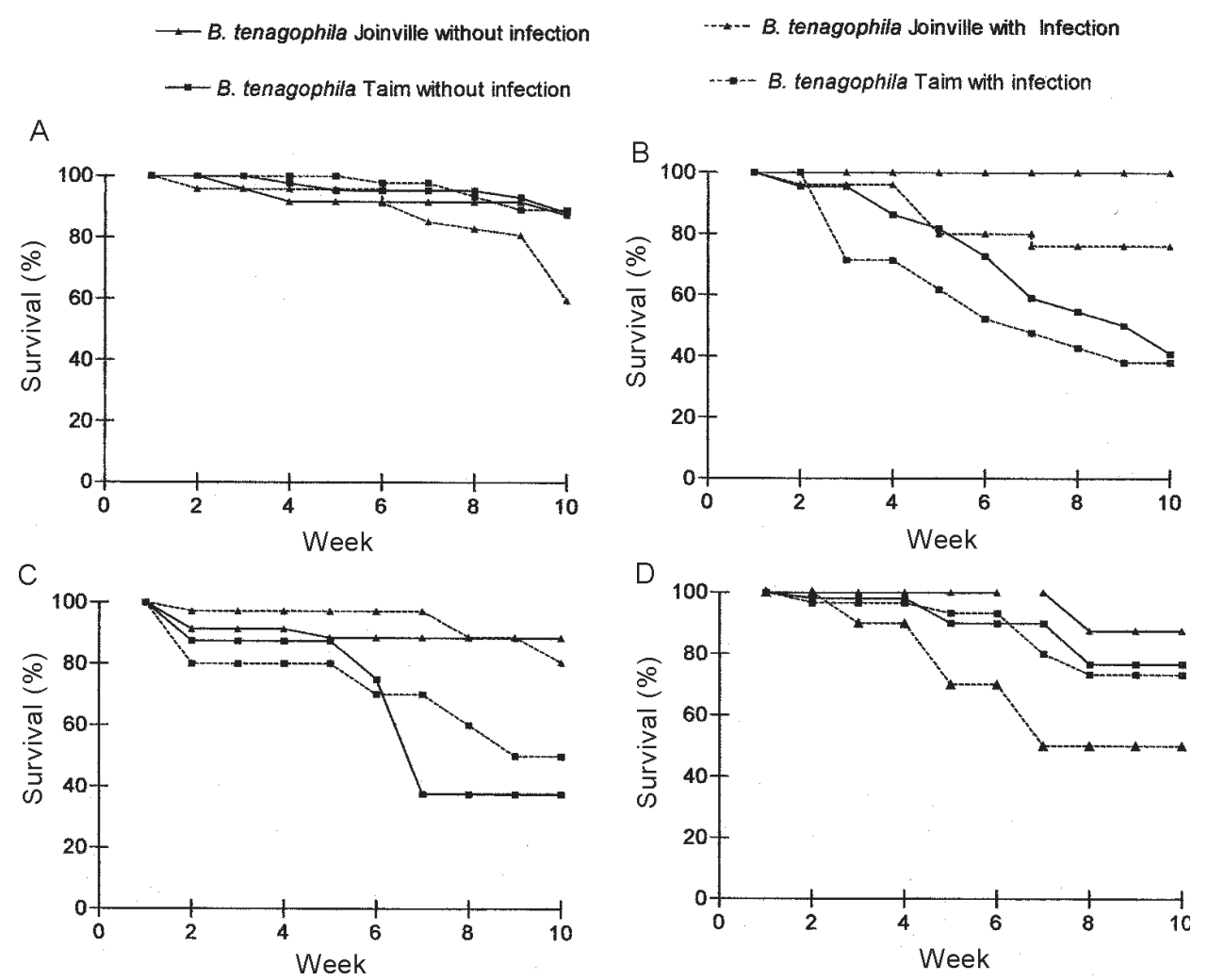

Fig. 1: surviving rate of Biomphalaria tenagophila Taim (R) and B. tenagophila Joinville (S) populations, submitted or not to Schistosoma mansoni pressure. A: G1-50 R and G2-50 S without infection; G6-50 R and G7-50 S with infection; B: G3-25 R + $25 \mathrm{~S}$ without infection; G8-25 R + 25 S with infection; C: G4-10 R + 40 S without infection; G9-10 R + 40 S with infection; D: G5-40 R + $10 \mathrm{~S}$ without infection; G10-40 R + $10 \mathrm{~S}$ with infection.

In breeding groups composed by mixed population of B. tenagophila Taim and Joinville, parasite infection also resulted in decreased survival rate of $S$. mansoni susceptible snails (Fig. 1B, C, D). However, in this mixed snail population, where the proportion of Taim and Joinville was similar or had more Joinville (Fig. 1B, C), Taim snails had survival rate inferior to $50 \%$, irrespective of the parasite infection. In contrast, in the mixed snail population with higher proportion of Taim stain, the survival rate of the resistant snail was elevated (70-80\%), while only $50 \%$ of the $B$. tenagophila Joinville population were able to survive after parasite exposition.

The B. tenagophila Taim was more fecund than $B$. tenagophila Joinville (Table II). Significant differences (p $=0.0039)$ could be observed when the number of eggs/ snail in Group 1 (B. tenagophila Taim) was compared with Group 2 (B. tenagophila Joinville). The same occurred when the number of eggs/snail in those two populations was analyzed, presenting $\mathrm{p}<0.014$ as a result (groups 6 and 7). The number of eggs/egglaying in Groups 1 and 2 was not significant, conversely Groups 6 and 7 presented highly significant values $(p=0.0001)$. When we compared the fecundity parameters of the infected susceptible population (Group 7) and those ones of the uninfected population (Group 2), a decrease could be observed, mainly in the number of eggs in the infected group, but the values were not significant. It appears that the parasite was unable diminishing significantly the egglaying in the infected snails. When both populations were compared, the number of surviving $\mathrm{F}_{1}$ descendants of $B$. tenagophila Taim was higher than those ones of $B$. tenagophila Joinville. The high proportion of pigmented snails obtained in $\mathrm{F}_{1}$ and $\mathrm{F}_{2}$ generations in the groups 3 , 4, 5, 8, 9 and 10, suggested that cross-breeding between pigmented B. tenagophila Taim and albino B. tenagophila Joinville populations occurred (Tables III, IV).

The $\mathrm{F}_{1}$ and $\mathrm{F}_{2}$ progeny obtained from cross-breeding group containing only $B$. tenagophila Joinville showed susceptibility rate to $S$. mansoni infection superior to $55 \%$, similarly to the susceptilibity rate observed in parental group, while the complete resistance of $B$. tenagophila Taim was confirmed through the generations (Table V). $\mathrm{F}_{1}$ generation obtained by cross-breeding between resistant and susceptible lineages was completely resistant to $S$. mansoni infection, irrespective of the Taim proportion. Moreover, less than $5 \%$ of $\mathrm{F}_{2}$ progeny were susceptible to $S$. mansoni infection. Therefore, even with higher mortality rate of parental group, $B$. tenagophila Taim snails presented a markedly better reproductive performance and were able to transmit the resistance character to their descendants. The results obtained with $\mathrm{F}_{1}$ and $\mathrm{F}_{2}$ generations after the susceptibility trial corroborate this hypothesis. 
TABLE II

Mean fecundity per week, in the parental breeding-group and total number of surviving $\mathrm{F}_{1}$ individuals after 30 days hatching

\begin{tabular}{lcccccc}
\hline Group & $\begin{array}{c}\text { Number of } \\
\text { egg-masses }\end{array}$ & $\begin{array}{c}\text { Number of } \\
\text { eggs }\end{array}$ & $\begin{array}{c}\text { Number of } \\
\text { egg-masses per snail }\end{array}$ & $\begin{array}{c}\text { Number of } \\
\text { eggs/snail }\end{array}$ & $\begin{array}{c}\text { Number of } \\
\text { eggs/egg-masses }\end{array}$ & $\begin{array}{c}\text { Total number of } \\
\text { surviving } F_{1} \text { individuals }\end{array}$ \\
\hline $1-50 R$ & 70.1 & 1129 & 2.03 & 27 & 15.0 & 2298 \\
$2-50 \mathrm{~S}$ & 62.2 & 778.4 & 1.37 & 17.11 & 11.5 & 1050 \\
$3-25 \mathrm{R}+25 \mathrm{R}$ & 69.1 & 718 & 1.71 & 17.59 & 9.92 & 800 \\
$4-10 \mathrm{R}+40 \mathrm{~S}$ & 40.9 & 539.4 & 1.08 & 14.35 & 12.95 & 540 \\
$5-40 \mathrm{R}+10 \mathrm{~S}$ & 51 & 663 & 1.85 & 18.9 & 13.31 & 1010 \\
$6-50 \mathrm{R}$ & 69 & 1300 & 1.52 & 29.2 & 20.4 & 2796 \\
$7-50 \mathrm{~S}$ & 52.2 & 505 & 1.20 & 11.94 & 9.51 & 922 \\
$8-25 \mathrm{R}+25 \mathrm{~S}$ & 59.4 & 585 & 1.69 & 16.77 & 9.10 & 630 \\
$9-10 \mathrm{R}+40 \mathrm{~S}$ & 44.2 & 443 & 1.05 & 10.43 & 8.8 & 470 \\
$10-40 \mathrm{R}+10 \mathrm{~S}$ & 44.9 & 523 & 2.31 & 14.94 & 10.53 & 932 \\
\hline
\end{tabular}

TABLE III

Percentage of pigmented and albino $\mathrm{F}_{1}$ progeny snails obtained by cross-breeding between susceptible and resistant adult snails

\begin{tabular}{lcc}
\hline Parental group & \% pigmented & $\%$ albino \\
\hline 50-R (Taim) & 100 & 0 \\
2-50S (Joinville) & 0 & 100 \\
3-25R+25S & 90 & 10 \\
4-40S+10R & 70 & 30 \\
5-40R+10S & 99 & 1 \\
6-50R(Taim) & 100 & 0 \\
7-50S (Joinville) & 0 & 100 \\
8-25R+25S & 97 & 3 \\
9-40S+10R & 87 & 13 \\
10-40R+10S & 100 & 0 \\
\hline
\end{tabular}

\section{TABLE IV}

Percentage of pigmented and albino $\mathrm{F}_{2}$ progeny snails obtained by cross-breeding between adult F1 X F1

\begin{tabular}{lcc}
\hline Parental group & \% pigmented & \% albino \\
\hline 50-R (Taim) & 100 & 0 \\
2-50S (Joinville) & 0 & 100 \\
3-25R+25S & 75 & 25 \\
4-40S+10R & 80 & 20 \\
5-40R+10S & 86 & 14 \\
6-50R(Taim) & 100 & 0 \\
7-50S (Joinville) & 0 & 100 \\
8-25R+25S & 79 & 21 \\
9-40S+10R & 81 & 19 \\
10-40R+10S & 85 & 15 \\
\hline
\end{tabular}

TABLE V

Susceptibility rate of $\mathrm{F}_{1}$ and $\mathrm{F}_{2}$ pigmented snails individually infected with Schistosoma mansoni

\begin{tabular}{lcc}
\hline Parental group & $\begin{array}{r}\text { Positive surviving } \\
\text { snails } \%\left(\mathrm{~F}_{1}\right)\end{array}$ & $\begin{array}{r}\text { Positive surviving } \\
\text { snails } \%\left(\mathrm{~F}_{2}\right)\end{array}$ \\
\hline 50-R (Taim) & 0 & 0 \\
2-50S (Joinville) & 62.5 & 68.1 \\
3-25R+25S & 0 & 5.0 \\
4-40S+10R & 0 & 4.5 \\
5-40R+10S & 0 & 0 \\
6-50R(Taim) & 0 & 0 \\
7-50S (Joinville) & 50 & 55 \\
8-25R+25S & 0 & 0 \\
9-40S+10R & 0 & 2.4 \\
10-40R+10S & 0 & 2.4 \\
\hline
\end{tabular}

\section{DISCUSSION}

Throughout an 18-month-experimental period, we studied the populational dynamics of resistant and susceptible strains of $B$. tenagophila. The two populations were maintained together, at different proportions of individuals, with and without $S$. mansoni pressure. The first point to be discussed is the question about the natural selection in those two populations. The presence of S. mansoni in susceptible snails represents a disease with devastating effects, since it causes a high mortality in the infected snails and a decrease in the egg-laying, thus becoming an element of natural selection, which is highly negative for the potentially transmitter snails of schistosomiasis (Coelho 1995). The lineage of B. tenagophila Joinville suffers the effect of infection, and this was observed due to the high mortality rate and a slight reduction in the number of eggs per snail in this population.

It could be observed that the parental populations submitted to pressure of the parasite presented a lower number of albino $\mathrm{F}_{1}$ individuals, when compared with the uninfected groups. Probably, this result could be related to reduction of the susceptible albino parental population itself. This experiment underwent the interference of another factor, possibly competition (Groups 3, 8, 4, 9). B. tenagophila Taim lineage presented on the one hand a drawback, i.e., a higher mortality rate without pressure of the parasite. On the other hand, this lineage presented a markedly a superior reproductive capacity studies carried out in our laboratories confirmed that $B$. tenagophila Taim was more fecund than $B$. tenagophila Joinville. This can be accounted for by the fact that a higher number of $\mathrm{F}_{1}$ surviving snails from $B$. tenagophila Taim population was obtained.

In all groups, the individuals pertaining to $\mathrm{F}_{1}$ generation were almost all predominantly pigmented. The proportion between pigmented and albino individuals detected in $\mathrm{F}_{2}$ generation showed that a cross-breeding occurred between parenteral $B$. tenagophila Taim $\times$ albino $B$. tenagophila Joinville. The recessive albino character was used, in this case, as a phenotypic marker, which facilitates distinction between $F_{1}$ individuals generated by cross-breeding (all of them being pigmented) and those ones generated by self-fecundation (albino). Paraense 
(1955) demonstrated that those individuals performed selffecundation only when they were isolated, otherwise they always preferred cross-breeding (when in the presence of one or more individuals).

Analyzing the resistance phenotype of $\mathrm{F}_{1}$ and $\mathrm{F}_{2}$ individuals, it was observed that, in this experiment, a predominance of resistant individuals occurred in all groups. Lewis et al. (2002) analyzed the genic flux of the resistance character in $\mathrm{F}_{1}$ descendants generated by crossbreeding between a resistant strain of B. glabrata and a susceptible one of the same species. The results obtained showed that the number of resistant $F_{1}$ individuals was higher than the number of susceptible ones. Based on the results obtained in this study, and taking into account studies carried out on the resistant B. tenagophila Taim strain throughout the last 27 years, our research group proposes a biological control model for schistosomiasis. The idea is to introduce the genetic characters of the resistant strain into the susceptible populations in endemic areas maintained by B. tenagophila (Coelho et al. 2004). It is expected that after a drastic reduction of the local population in the transmitter focus as, for example, after the use of moluscicide, the introduction of the resistant Taim lineage on a large scale would force the surviving individuals to perform cross-breeding with the introduced lineage. Their descendants would be endowed with the desired dominant character of resistance to the parasite, and would inherite the adaptative capacity to the local environment of their local ascendants as well.

The molecular marker, which is typical of the Taim lineage, although being not associated to resistance, has a dominant character too (Rosa et al. 2004). This marker is represented by the band with $350 \mathrm{bp}$ of the ITS region of the ribosomal mitochondrial DNA detected by PCR-RFLP technique, using $D d e l$ I enzyme. This marker will be of great importance for the follow-up, and to demonstrate the success obtained with the insertion of the genetic characteristics of the Taim lineage into the population after intervention. This model has been already used in focuses located in Bananal and Caraguatatuba - two cities in the state of São Paulo, Brazil, in a collaborative work with Sucen, UFMG, and Fiocruz. In those focuses, moluscicides were not previously used. This experimental approach was approved by Ibama, the Brazilian official agency that control environmental interventions.

The success of introduction of the genetic characteristics of resistance will be confirmed by the presence of the molecular marker of Taim lineage in the snails born after intervention, and by means of tests related to susceptibility to $S$. mansoni carried out with these progenies, when compared with those ones of the local strain, that was isolated before introduction of the Taim lineage.

\section{ACKNOWLEDGEMENTS}

To Dr Maria Lúcia Prado Uchôa Maciel, owner of the "Chácara Santa Inês", Bananal/SP, to the Biologist Marta Leonia Valiante, as well as to the technicians João Batista dos Santos, Jefferson Bernardes do Carmo, and Selma Fernandes de Souza. To Mirian Ferreira de Oliveira Bruno, Prefect of Bananal, state of São Paulo, for her valuable support to our project.

\section{REFERENCES}

Coelho PM 1995. Resistência e suscetibilidade à infecção por Schistosoma mansoni em caramujos do gênero Biomphalaria. In FS Barbosa, Tópicos em Malacologia Médica, Fiocruz, p. 208-217.

Coelho PMZ, Carvalho OS, Andrade ZA, Martins-Sousa RL, Rosa FM, Barbosa L, Pereira CAJ, Caldeira RL, Passos LJ, Godard ALB, Moreira LA, Oliveira GC, Franco GR, Teles HMS, Negrão-Côrrea D 2004. Biomphalaria tenagophila/ Schistosoma mansoni interaction: premises for a new approach to biological control of schistosomiasis. Mem Inst Oswaldo Cruz 99 (Suppl.1): 109-111.

Freitas JR, Boschi MB, Santos MBL 1985. Suscetibilidade de "híbridos" de Biomphalaria tenagophila à cepa LE (BH) do Schistosoma mansoni. Rev Inst Med Trop São Paulo 1: 6-12.

Lewis AF, Patterson CN, Grzwacz C 2002. Parasite- susceptibility phenotypes of $\mathrm{F}_{1}$ Biomphalaria glabrata progeny derived from interbreeding Schistosoma mansoni-resistant and susceptible snails. Parasitol Res 89: 98-101.

Paraense WL 1955. Autofecundação e fecundação cruzada em Australorbis glabratus. Mem Inst Oswaldo Cruz 53: 277284.

Paraense WL, Corrêa LR 1978. Differential susceptibility of Biomphalaria tenagophila populations to infection with a strain of Schistosoma mansoni. J Parasitol 64: 822-826.

Paraense WL, Corrêa LR 1987. Probable extension of schistosomiasis mansoni to southern Brazil. Mem Inst Oswaldo Cruz 82: 577.

Pellegrino J, Katz N 1968. Experimental chemotherapy of schistosomiasis mansoni. Adv Parasitol 6: 233-290.

Rosa FM, Caldeira RL, Carvalho OS, Godard ALB, Coelho PMZ 2004. Dominant character of the molecular marker of Biomphalaria tenagophila (Mollusca: Planorbidae) strain, resistant to Schistosoma mansoni. Mem Inst Oswaldo Cruz 99: 85-87.

Rosa FM, Godard ALB, Azevedo V, Coelho PMZ 2005. Biomphalaria tenagophila: dominant character of the resistance to Schistosoma mansoni and descendants of crossbreeding between resistant (Taim, RS) and susceptible (Joinville, SC) strains. Mem Inst Oswaldo Cruz 100: 19-23.

Santos MBL, Freitas JR, Correia MCR 1979. Suscetibilidade ao Schistosoma mansoni de hibridos de Biomphalaria tenagophila do Taim, RS, Cabo Frio, RJ, e Belo Horizonte, MG. Rev Inst Med Trop São Paulo 21: 281-286. 
